\title{
Isolasi Jamur dari Batuan Penutup Drainase Pada Sisi Selatan Lantai II Bidang H Candi Borobudur
}

\author{
Nabiilah Ardini Fauziyyah, Dina Aurum Sari Putri \\ Sekolah Ilmu dan Teknologi Hayati, Institut Teknologi Bandung \\ Email : nabiilah.ardini@gmail.com, dinaaurumsp@gmail.com
}

\begin{abstract}
Abstrak : Penelitian ini bertujuan untuk mengisolasi jamur dari batuan penutup drainase Candi Borobudur pada sisi Selatan Lantai II Bidang H, yang memiliki kemungkinan menyebabkan biodeteriorasi. Kerak pada batuan penutup drainase disampling dengan metode kerik dan swab, kemudian dilakukan isolasi mikroba hasil sampling dengan metode spread, streak, dan tabur pada medium Nutrient Agar dan Potato Dextrose Agar. Inkubasi dilakukan pada suhu $28^{\circ} \mathrm{C}$ dengan kelembaban $80 \%$ selama $24-48$ jam. Isolat yang berbeda disubkultur pada medium baru dan diinkubasi kembali selama 48-72 jam dengan suhu dan kelembaban yang sama. Setelah isolat diinkubasi, dilakukan karakterisasi morfologi makroskopis berupa bentuk dan warna koloni isolat jamur, dan mikroskopis berupa keberadaan septa pada hifa, spora, dan kantung spora dengan mikroskop. Didapatkan empat isolat jamur yaitu J1, J2, J6, dan J7. Berdasarkan morfologi makroskopis dan mikroskopis, Isolat J1, J6, dan J7 termasuk jenis jamur dari filum Ascomycota atau Deutromycota sedangkan Isolat J2 termasuk jenis jamur dari filum Zygomycota.
\end{abstract}

Kata kunci : Biodeteriorasi, Candi Borobudur, Isolasi, Jamur, Karakterisasi Morfologis

\begin{abstract}
The purposes of this study is to isolate the molds from the rock that covers the drainage system of Borobudur on the southern side floor II sector $\mathrm{H}$, which has the possibility for causing biodeterioration. The crust on the rock surface is being sampled with a chisel and swabbed with a sterile cotton bud. Both samples are transfered into the lab then the isolation of microbes is performed with spread method, streak method, and also by sowing the crust samples onto the gelatine Nutrient Agar and Potato Dextrose Agar aseptically. The inoculated samples were incubated for $24-72$ hours at $28^{\circ} \mathrm{C}$ with $80 \%$ humidity. Different molds isolates were subcultured into new medium and incubated for 48-72 hours with the same temperature and humidity as before. After incubation, the fungal isolates were characterized for its macroscopic and microscopic morphology. Macroscopic characterization was carried out by defining the colony shapes and colors of the isolates. Microscopic characterization was carried out by defining the existence of septae in hyphae, form of the spores and spore sac with a microscope. Four isolates were obtained (J1, J2, J6 and J7). Based on macroscopic and microscopic morphology, isolates J1, J6 and $\mathrm{J} 7$ are from the phylum Ascomycota or Fungi Imperfecti while isolates J2 isfrom the phylum Zygomycota.
\end{abstract}

Keywords : Biodeterioration, Borobudur temple,Isolation, Molds, Morphological characterization

\section{Pendahuluan}

\section{A. Latar Belakang}

Candi Borobudur adalah struktur peninggalan purbakala yang berlokasi di daerah Borobudur, Magelang, Jawa Tengah, Indonesia. Candi Borobudur adalah struktur candi Buddha tunggal terbesar di dunia yang terus dijaga kelestariannya. Namun demikian, secara umum, batuan Candi Borobudur telah mengalami pelapukan yang apabila dibiarkan dapat berujung pada kerusakan material batuan, relief, dan konstruksi dasar candi. Pelapukan tersebut dapat terjadi karena berbagai faktor. Berdasarkan penyebabnya, pelapukan dibagi menjadi tiga yaitu pelapukan akibat proses fisika, kimia, dan biologi (Pujiastuti et al, 2006). Pelapukan akibat agen biologis kerap ditemukan pada batuan Candi Borobudur. Mikroorganisme jamur merupakan agen biologis yang sering ditemukan menjadi agen pelapuk batuan. Selain itu, jamur juga dapat bersimbiosis dengan cyanobacteria dan membentuk lichen yang juga dapat melapukkan batuan (Margulis dan Barreno, 2003).

Sejak penemuannya pada tahun 1814, telah dilakukan beberapa kali pemugaran pada Candi Borobudur. Pemugaran pada tahun 1973-1983 menambahkan sistem drainase pada Candi Borobudur untuk mencegah terjadinya genangan air pada bagian dalam candi dan teras candi. Terjadinya genangan air dapat meningkatkan kelembaban dan memicu tumbuhnya mikroorganisme dan lichen penyebab pelapukan candi. Selain itu, untuk mencegah terkikisnya tanah dan batuan di bagian dalam Candi Borobudur karena air, sehingga kerusakan candi dapat dicegah (Anom, 2005).

Namun setelah erupsi Merapi tahun 2010 dan 
erupsi Kelud tahun 2014, telah dilaporkan beberapa masalah dalam sistem drainase Candi Borobudur yaitu keberadaan abu vulkanik pada saluran drainase lantai II, III, dan IV, tepatnya pada bagian filter (saringan) drainase di bawah batuan candi. Selain itu terdapat ancaman kerusakan batuan yang cukup kompleks, antara lain akibat rembesan air yang membawa material ke dalam rongga batuan tempat sistem drainase berada. Meterial itu kemudian menjadi kerak dan bintik (postule) yang mengganggu kelestarian batu candi dan relief (Atmoko, 2016).

Postule tersebut belum teridentifikasi namun diduga jamur atau mengandung jamur karena memiliki bentuk persebaran yang spotting dan radial seperti bentuk persebaran jamur. Keberadaan jamur pada batuan drainase candi borobudur dapat memicu pelapukan ke tahap yang lebih parah. Oleh karena itu perlu dilakukan penelitian mengenai keberadaan jamur yang tumbuh pada batuan penutup drainase Candi Borobudur.

Penelitian ini bertujuan untuk mengisolasi jamur yang tumbuh pada batuan penutup sistem drainase pada sisi selatan lantai II bidang H (S2H) Candi Borobudur. Isolat yang ditemukan kemudian juga dikarakterisasi morfologi makroskopis dan mikroskopisnya. Hasil penelitian diharapkan dapat digunakan dalam penelitian selanjutnya guna mengetahui secara lebih spesifik jenis dan peran jamur tersebut dalam pelapukan batuan Candi Borobudur.

\section{B. Metode}

Secara garis besar, metode penelitian ini terdiri dari 3 tahapan yaitu sampling mikroba di lapangan, isolasi jamur, dan karaterisasi isolat jamur yang ditemukan.

\section{Sampling Mikroba di Lapangan}

Sampling dilakukan pada sisi batuan penutup drainase Candi Borobudur pada sisi selatan lantai II bidang $\mathrm{H}(\mathrm{S} 2 \mathrm{H})$, yang menampakkan kerak berwarna putih kekuningan. Pada bagian tersebut dilakukan pengamatan dengan Handy-Microscope kemudian dilakukan sampling dengan metode swab dan kerik.

Metode swab dilakukan dengan mengambil apusan batu yang memiliki bercak putih dengan cotton bud steril yang telah dibasahi sedikit dengan akuades. Pembasahan dengan akuades bertujuan untuk melembabkan cotton bud sehingga spora pada sampel batuan lebih mudah menempel pada cotton bud. Cotton bud yang telah dipenuhi apusan dibungkus dengan alumunium foil steril kemudian dipindahkan ke lab dan di analisis dalam rentang waktu 24 jam. Sampling dilakukan untuk apusan jamur dan apusan bakteri, masing-masing dilakukan duplo. Dilakukan sampling untuk apusan bakteri untuk menambah data penelitian berupa adanya kemungkinan bakteri yang juga tumbuh pada lokasi sampling, yang dapat berguna untuk penelitian selanjutnya.

Metode kerik dilakukan dengan mengambil bagian batu yang memiliki bercak putih dengan menggunakan skapel. Dilakukan 2 kali kerikan untuk sampel kerikan bakteri dan sampel kerikan jamur. Sampel kerikan ditampung dalam plastik ziplock steril kemudian dipindahkan ke lab dan dianalisis dalam rentang waktu 24 jam.

\section{Isolasi Jamur}

Isolasi dilakukan pada medium Potato Dextrose Agar (PDA) karena baik untuk pertumbuhan fungi dan Nutrient Agar(NA) karena baik untuk pertumbuhan bakteri dalam cawan petri. Dilakukan 3 metode isolasi yaitu spread, streak, dan tabur.

Metode streak dilakukan dengan menggoreskan hasil swab pada permukaan medium secara aseptis. Cawan petri kemudian diinkubasi pada suhu $28^{\circ} \mathrm{C}$ dengan kelembaban $80 \%$ selama $24-72$ jam.

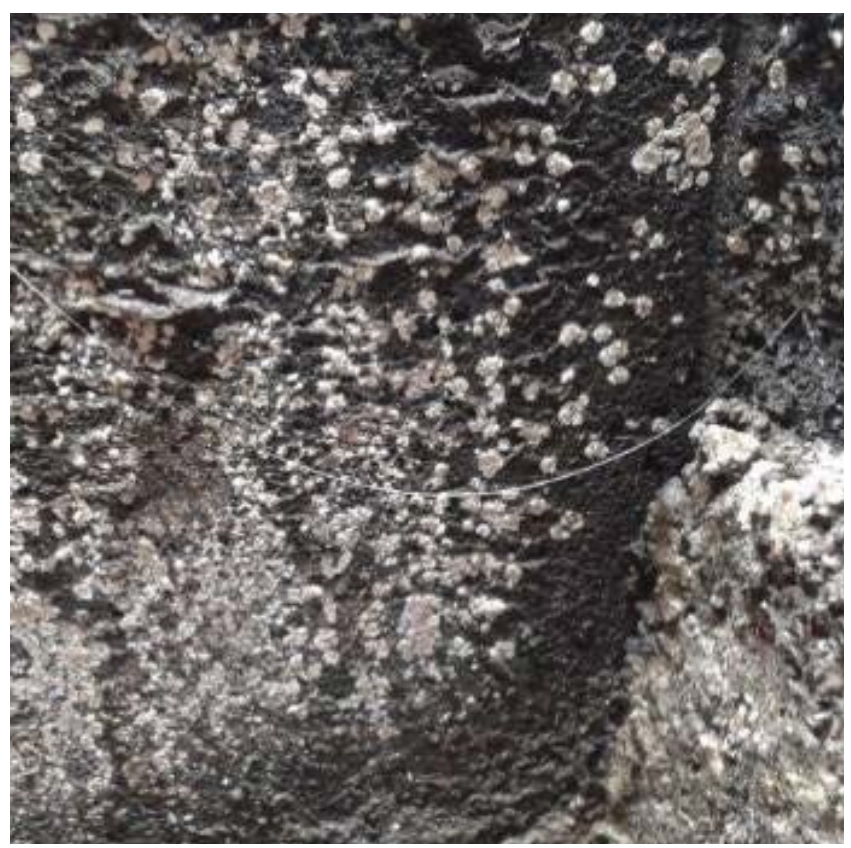

Foto 1. Tampak kerak yang diduga merupakan mikroorganisme di sisi batuan penutup drainase Candi Borobudur pada sisi selatan lantai II bidang $\mathrm{H}$. 
Metode spread dilakukan dengan memasukkan secara aseptis masing-masing sampel kerikan (bakteri dan jamur) ke dalam akuades steril yang berbeda. Masingmasing larutan sampel kemudian dihomogenisasi. Pada $100 \mu \mathrm{L}$ larutan sampel kemudian diinokulasikan secara spread ke permukaan medium. Cawan petri kemudian diinkubasi pada suhu $28^{\circ} \mathrm{C}$ dengan kelembaban $80 \%$ selama 24-72 jam.

Metode tabur dilakukan dengan menabur secara aseptis sampel kerikan ke permukaan medium. menggunakan spatula. Cawan petri kemudian diinkubasi pada suhu $28^{\circ} \mathrm{C}$ dengan kelembaban $80 \%$ selama $24-72$ jam.

Jamur yang tumbuh dan memiliki morfologi yang berbeda kemudian disubkultur dengan metode tanam secara aseptis ke PDA miring pada tabung reaksi untuk dikarakterisasi lebih lanjut. Subkultur dilakukan untuk mendapatkan isolat murni jamur. Metode tanam dilakukan dengan mengambil bagian miselium jamur pada permukaan agar dengan spatula kemudian diletakan terbalik pada medium agar yang baru. PDA miring yang telah terinokulasi diinkubasi pada suhu $28^{\circ} \mathrm{C}$ dengan kelembaban 80\% selama 48-72 jam.

\section{Karakterisasi Isolat Jamur}

Karakterisasi isolat dilakukan dengan menentukan morfologi makroskopis dan mikroskopis isolat jamur. Morfologi makroskopis ditentukan dengan mengamati secara mata telanjang bentuk dan warna koloni isolat jamur. Penentuan morfologi mikroskopis isolat jamur dilakukan dengan membuat preparat basah jamur kemudian diamati dibawah mikroskop. Hal yang diamati meliputi bentuk hifa (keberadaan septa pada hifa), spora, dan kantung spora.

\section{Pembahasan}

\section{A. Pengamatan pada Lokasi Sampling}

Pada lokasi sampling, teramati kerak berwarna putih kekuningan memiliki bentuk persebaran yang spotting dan radial. Setelah dilakukan pengamatan menggunakan handy-microscope dengan perbesaran 150x, didapatkan bentuk kerak yang menyerupai lichen tipe crustoce karena berbentuk kerak yang menempel pada permukaan (Budel dan Scheidegger, 1996).

Kerak berwarna putih kekuningan dominan menempati sisi batuan yang pasir terlapisi oleh substansi yang menyerupai atau tanah. Pasir atau tanah ini diduga adalah sisa-sisa abu vulkanik yang belum terbersihkan setelah erupsi Merapi tahun 2010 dan erupsi Kelud tahun 2014. Abu vulkanik mengandung mikronutrien seperti fosfat dan sulfur yang beragam, kalsium yang cukup tinggi, dan kandungan besi, mangan, timbal, serta cadmiun yang rendah (Suriadikarta, 2012). Kandungan ini mampu dimanfaatkan oleh mikroorganisme kemolitotrof yaitu pengguna mineral anorganik untuk pertumbuhan, yang selanjutnya dapat memicu pertumbuhan organisme lain seperti jamur, algae, lichen, dan organisme tingkat tinggi (Brem dan Lips, 2008).

\section{B. Isolat Mikroba}

Hasil sampling mikroba dengan metode swab dan kerik dianalisis di lab dalam kurun waktu 24 jam. Dari 7 cawan petri didapat 6 isolat bakteri (B3, B4, B5, B9, B10, B11) dan 5 isolat jamur (J1, J2, J6, J7, J8) yang berbeda. Isolat bakteri dibedakan berdasarkan warna koloni, bentuk koloni dan pola pertumbuhan koloni pada permukaan agar. Sedangkan isolat jamur dibedakan secara maksroskopis dilihat dari warna spora dan bentuk
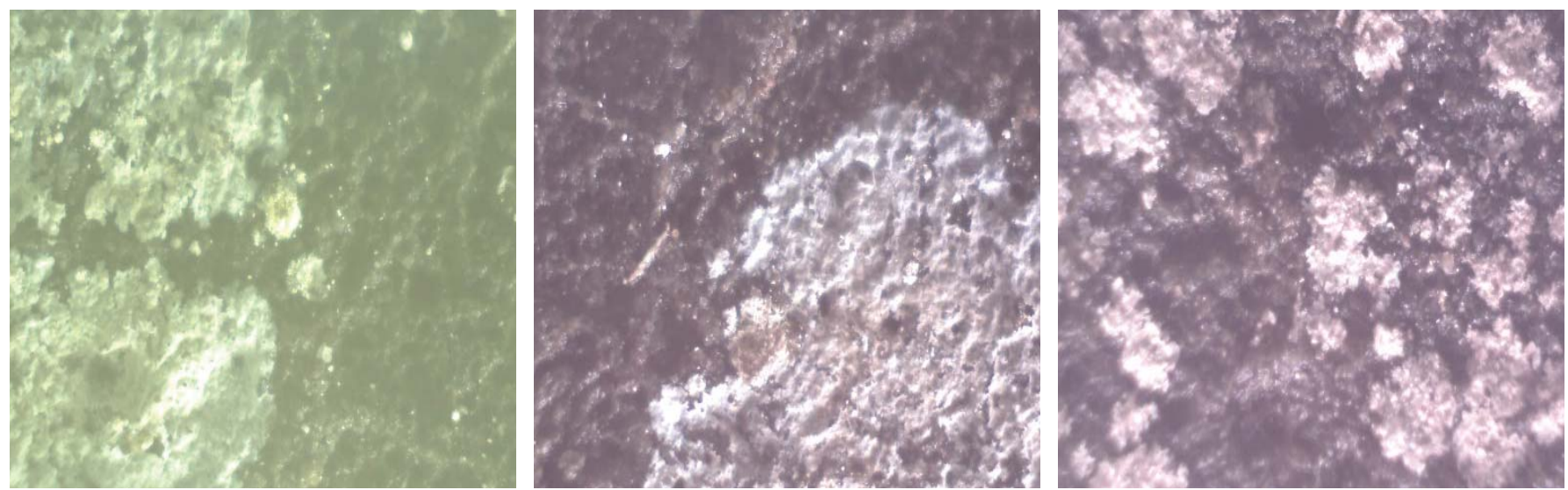

Foto 2. Kerak pada batuan penutup drainase Candi Borobudur pada sisi selatan lantai II bidang Hdengan perbesaran handy-microscope 150x. 
Tabel 1. Morfologi Makroskopis Dan Mikroskopis Isolat Jamur.

\begin{tabular}{|c|c|c|c|c|c|}
\hline \multirow{4}{*}{$\begin{array}{l}\text { ISOLAT } \\
\text { JAMUR }\end{array}$} & \multirow{2}{*}{\multicolumn{2}{|c|}{ MORFOLOGI MAKROSKOPIS }} & \multicolumn{3}{|c|}{ MORFOLOGI MAKROSKOPIS } \\
\hline & & & \multicolumn{2}{|c|}{ HIFA } & \multirow{3}{*}{$\begin{array}{l}\text { ALAT REPRODUKSI } \\
\text { YANG DITEMUKA }\end{array}$} \\
\hline & 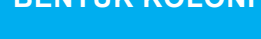 & & & & \\
\hline & & & BERSEPTA & BERCABANG & \\
\hline $\mathrm{J} 1$ & $\begin{array}{l}\text { Miselium } \\
\text { memenuhi } \\
\text { tabung }\end{array}$ & Peach & $\mathrm{v}$ & $\mathrm{v}$ & Mikrokonidium \\
\hline $\mathrm{J} 2$ & $\begin{array}{l}\text { Miselium } \\
\text { memenuhi } \\
\text { tabung }\end{array}$ & Hitam & v & $\mathrm{v}$ & $\begin{array}{l}\text { Sporangium dan } \\
\text { sporangiospora }\end{array}$ \\
\hline J6 & Iregular & Kuning & $v$ & $v$ & Cladosporium \\
\hline J7 & Sirkular & Hijau gelap & v & v & $\begin{array}{l}\text { Tangkai konidiofor } \\
\text { kompleks \& spora } \\
\text { mikrokonidium }\end{array}$ \\
\hline
\end{tabular}

koloni jamur.

Dari kelima isolat jamur yang ditemukan, 4 isolat (J1, J2, J6, J7) berhasil disubkultur pada tabung reaksi yang berisi PDA miring dan diinkubasi selama 48-72 jam pada suhu $28^{\circ} \mathrm{C}$ dengan kelembaban $80 \%$. Isolat J8 tidak berhasil di subkultur karena pada proses subkultur, isolat mengalami kerusakan dan terkontaminasi oleh bakteri. Sementara itu keenam isolat bakteri tidak dikarakterisasi lebih lanjut karena berada diluar ruang lingkup penelitian.

Setelah inkubasi, keempat isolat murni jamur dengan morfologi yang berbeda dikarakterisasi dan didapatkan data sebagaimana tertera pada Tabel 1. Keempat isolat jamur termasuk kedalam kelompok molds. Hasil pengamatan makroskopis dan mikroskopis dapat membantu identifikasi isolat jamur.

Secara makroskopis, isolat J1 memiliki spora berwarna peach, miselium merambat ke atas menuju tutup tabung dan memenuhi sebagian tabung reaksi. Pada pengamatan menggunakan mikroskop dengan perbesaran 1000x, isolat J1 memiliki spora aseksual mikrokonodium, hifa bersepta dan bercabang. Dengan karakter tersebut, maka diperkirakan isolat J1 termasuk di filum Ascomycota atau Deutromycota.

Secara makroskopis isolat J2 memiliki spora berwarna hitam, miselium merambat ke atas dan memenuhi tabung. Pada pengamatan menggunakan mikroskop dengan perbesaran 1000x, isolat J2 memiliki hifa bersepta, hifa bercabang, kantong spora berupa sporangium dan menghasilkan sporangiospora. Berdasarkan karakter tersebut, diperkirakan bahwa isolat J2 termasuk jamur dari filum Zygomycota.
Secara makroskopis isolat J6 memiliki spora berwarna kuning, koloni berbentuk iregular, dan miselium tidak memenuhi tabung. Pada pengamatan menggunakan mikroskop dengan perbesaran 1000x, diamati isolat nomor J6 memiliki hifa bersepta dan bercabang, tidak teramati kantung spora namun teramati tangkai berbentuk cladosporium, suatu bentuk dari tangkai konidiofor. Oleh karena itu diperkirakan isolat ini termasuk dalam filum jamur Ascomycota atau Deutromycota.

Secara makroskopis isolat nomor J7 memiliki spora berwarna hijau gelap, koloni tumbuh sirkular dan misellium tidak memenuhi tabung reaksi. Pada pengamatan menggunakan mikroskop dengan perbesaran 1000x, diamati isolat J7 memililiki hifa bercabang dan bersepta.Isolat juga memiliki spora mikrokonidium dan tangkai konidiofor kompleks. Oleh karena itu isolat J7 diperkirakan termasuk dalam filum Ascomycota atau Deutromycota.

\section{Peran Jamur pada Batuan Candi Borobudur}

Belum dilakukan penelitian lebih lanjut mengenai peran pasti isolat jamur yang ditemukan. Namun secara umum, jamur dapat merusak batuan secara mekanis maupun kimia. Secara mekanis, jamur dapat melakukan penetrasi ke material batuan melalui pertumbuhan hifa ke dalam batuan sehingga dapat memperbesar porositas batuan. Secara kimiawi, jamur memiliki kemampuan memproduksi pigmen dan asam organik yang menyebabkan dampak buruk pada material seperti perubahan warna dan degradasi dari beberapa tipe batu seperti contohnya pada pada batu peninggalan 


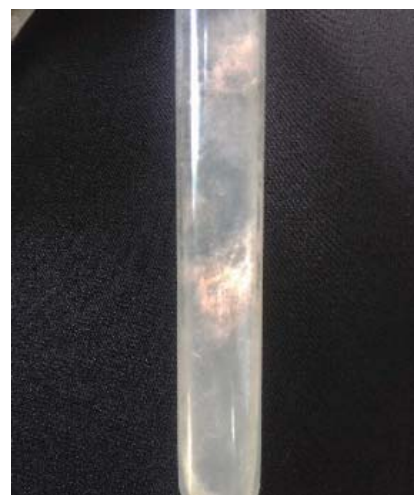

a

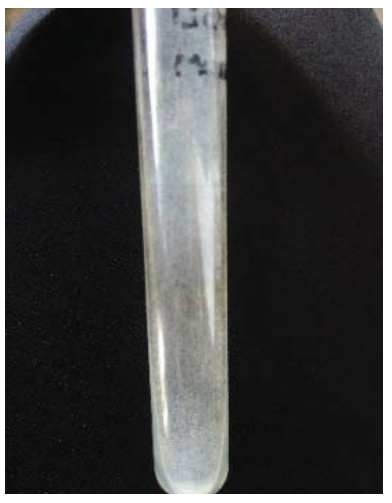

b

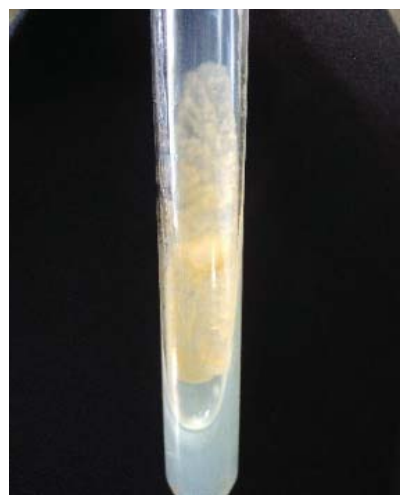

C

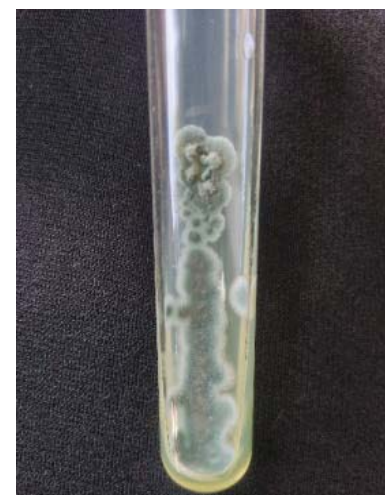

d

Foto 3. Tampak koloni isolat jamur secara berurutan pada medium PDA di tabung reaksi dengan umur 48 jam. (a) isolat J1 memiliki miselium yang memenuhi tabung dengan spora berwarna peach. (b) isolat J2 memiliki miselium yang memenuhi tabung dengan spora berwarna hitam. (c) isolat $\mathrm{J} 6$ memiliki bentuk yang iregular dengan spora berwarna kuning. (d) isolat $\mathrm{J7}$ memiliki spora hijau gelap dan koloninya berbentuk sirkular.

sejarah. Batuan tersebut dapat terpapar melanin dari jamur Dematiaceous atau black fungi yang umum ditemukan pada batuan di daerah yang beriklim hangat (Warscheid dan Braams, 2000).

Berdasarkan kemungkinan tersebut, perlu dilakukan identifikasi lebih lanjut mengenai spesies isolat jamur yang ditemukan dan penelitian mengenai peran atau mode of action isolat jamur tersebut dalam pelapukan batuan candi. Sehingga selanjutnya dapat ditentukan atau diciptakan metode penghambatan yang efektif untuk jamur atau mikroorganisme lain yang berperan dalam pelapukan batuan Candi Borobudur. Meskipun begitu, kondisi batuan yang terbebas dari jamur untuk jangka waktu yang lama memang sulit untuk dicapai. Namun

\section{DAFTAR PUSTAKA}

Anom, I.G.N. 2005. The Restoration of Borobudur. Belgia: UNESCO Publishing.

Atmoko, M.H. 2015. Masih Ada Abu Vulkanik di Drainase Borobudur [Online] http://www.antarajateng. com/detail/masih-ada-abu-vulkanik-didrainase-borobudur.html, diakses pada 19 Juli 2016

Budel, B. dan Scheidegger, C.1996. Thallus morphology and anatomy. In Nash, T. Lichen biology. Cambridge: Cambridge University Press.

Brem F.M. dan Lips, K.R. 2008.Batrachochytrium dendrobatidis infection patterns among Panamanian amphibian species, habitats and elevations during epizootic and enzootic stages. Diseases of Aquatic Organisms 81 (3).

Chaerun, S. K. 2010. Prinsip dan Mekanisme laju pelapukan dapat dicegah dengan membersihkan secara rutin batuan candi dengan kerik (tanpa air) dan pembersihan total sisa abu vulkanik yang menempel pada batuan

\section{Kesimpulan}

Berdasarkan penelitian yang dilakukan, didapat 4 isoat jamur yang dapat dikarakterisasi secara makroskopis maupun mikroskopis yaitu isolat J1, J2, J6 dan J7. Isolat J1 diperkirakan termasuk jenis jamur Ascomycota atau Deutromycota. Isolat $\mathrm{J} 2$ diperkirakan termasuk jenis jamur Zygomycota. Isolat J6 diperkirakan termasuk jamur Ascomycota atau Deutromycota.Isolat J7 diperkirakan termasuk jamur Ascomycota atau Deutromycota.

Biomineralasi. Presentasi Kuliah Biomineralogi. Sekolah Ilmu dan Teknologi Hayati, Institut Teknologi Bandung

Margulis, L. dan Barreno, E. 2003. Looking at Lichens. BioScience, 53 (8).

Pujiastuti, Y. S, et.al. 2006. IPS Terpadu 1A. Jakarta: Penerbit Erlangga

Sharnoff, S. 2014. Field Guide to California Lichens. Yale University Press

Suriadikarta, D.A. 2012. Kajian Cepat Dampak Erupsi Gunung Merapi 2010 terhadap Sumberdaya Laban Pertanian dan Inovasi Rehabilitasinya.Bogor: Kementerian Pertanian.

Warsheid, T dan Braams, J. 2000. Biodeterioration of stone: a review. Biodeterioration Biodegrad, 